\title{
Deep sea sedimentary analogs for the Vostok ice core
}

\author{
P. Graham Mortyn \\ Scripps Institution of Oceanography, La Jolla, California 92037, USA \\ Now at Department of Earth and Environmental Sciences, California State University, Fresno, MH-24, Fresno, \\ California 93740, USA.
}

Christopher D. Charles

Scripps Institution of Oceanography, La Jolla, California 92037, USA (ccharles@ucsd.edu)

Ulysses S. Ninnemann

Scripps Institution of Oceanography, La Jolla, California 92037, USA

Now at Department of Geology, University of Bergen, Allegaten 41, 5007 Bergen, Norway.

\section{Kristen Ludwig}

Scripps Institution of Oceanography, La Jolla, California 92037, USA

Now at School of Oceanography, University of Washington, Box 357940, Seattle, Washington 98195, USA.

\author{
David A. Hodell \\ Department of Geological Sciences, University of Florida, Gainesville, Florida 32611, USA
}

[1] Many applications of the Vostok ice core depend critically on the ability to make stratigraphic ties to marine records in the adjacent Southern Ocean. Here we present oxygen isotopic records from high accumulation rate sites in the South Atlantic sector of the Southern Ocean, collected for the purpose of complementing the recently extended $\delta \mathrm{D}$ record from the Vostok ice core. The combination of several planktonic foraminiferal $\delta^{18} \mathrm{O}$ records from northern subantarctic piston cores demonstrates that all of the millennial-scale oscillations expressed in the Vostok ice core over the last $60 \mathrm{ky}$ are also present in marine records. The observations also support the assumption that the millennial-scale oscillations common to both marine and ice archives are synchronous, thus providing a rationale for extending the marine-ice core comparison through the last 400,000 years, making use of a marine drilled core (ODP Site 1089). By aligning the phase of these common abrupt events, we anchor the Vostok chronology to an orbitally tuned marine sediment chronology - a refinement that allows examination of a variety of paleoclimatological issues such as the relationship between deep ocean variability and Antarctic polar climate. For example, this exercise suggests that, over at least the 4 major deglaciation events, the primary (orbital scale) changes in the chemistry and, most likely, the temperature of the deep Southern ocean were synchronous with changes in atmospheric $\mathrm{pCO}_{2}$ and polar air temperatures. We also find that the deuterium excess in the ice core resembles marine (foraminiferal) $\delta^{13} \mathrm{C}$ records and that the deuterium excess is synchronous with an "anomalous" foraminiferal $\delta^{18} \mathrm{O}$ signal (the residual between normalized versions of Vostok $\delta \mathrm{D}$ and foraminiferal $\delta^{18} \mathrm{O}$ ). These observations demand a tight link between the Vostok isotopic record and the airsea interaction of the subantarctic zone.

Components: 9680 words, 11 figures, 1 tables.

Keywords: Paleoclimatology. 
Index Terms: 4267 Oceanography: General: Paleoceanography; 3344 Meteorology and Atmospheric Dynamics: Paleoclimatology.

Received 12 November 2002; Revised 4 April 2003; Accepted 7 April 2003; Published 7 August 2003.

Mortyn, P. G., C. D. Charles, U. S. Ninnemann, K. Ludwig, D. A. Hodell, Deep sea sedimentary analogs for the Vostok ice core, Geochem. Geophys. Geosyst., 4(8), 8405, doi:10.1029/2002GC000475, 2003.

\section{Introduction}

[2] Antarctic ice cores have revolutionized the science of paleoclimatology by establishing perhaps the cleanest available record of climate variability over ice age cycles- including the climatic interactions associated with atmospheric greenhouse gases. For example, the paleotemperature records from the Antarctic ice cores can be used as a valuable gauge of global climate sensitivity [e.g., Lorius et al., 1990], and they can be used to test general circulation model projections of greenhouse warming. However, a general limitation of ice core archives is that most mechanisms proposed for large-scale climate (and atmospheric $\mathrm{CO}_{2}$ ) variability on timescales longer than decades involve the ocean. Therefore to be most useful, the ice core records must be integrated definitively with analogous records from marine sediments. This requirement has proven to be difficult to achieve, because there are few means to create a unified timescale.

[3] Lorius et al. [1979] made one of the original attempts to link a southern hemisphere marine record to that from an ice archive, the Dome $\mathrm{C}$ core in East Antarctica. This work was guided by the assumption that proxies for temperature in both types of records should be related genetically. Several subsequent studies [e.g., Pichon et al., 1992; Sowers et al., 1993; Charles et al., 1996; Ninnemann et al., 1999] have extended the same principle by comparing various high- latitude marine records of longer duration to Vostok [Petit et al., 1999]. However, several important uncertainties remain. For example, it has yet to be established whether marine records can be linked to the Vostok record on millennial timescales, especially for the periods predating typical radiocarbon chronologies. This level of precision in correlation is a necessary prerequisite for resolving the mechanisms of "abrupt" change in the ocean/climate system. Also, there is currently no agreement on the types of marine records that should be used for comparison to proxies of ice core air temperatures [e.g., Sowers et al., 1993], and it is still unclear to what degree spatial heterogeneity influences the essential climatic responses among all sectors of the Antarctic continent and Southern Ocean. As a result, any marine-ice stratigraphic ties that rely on the assumption of a common climatic signal might be questioned on the basis of geographical complexities (such as those expressed at Taylor Dome ice core, where the phase of climate variability was at times seemingly distinct from that of the central Antarctic Plateau [Steig et al., 1998]). On the other hand, any quantitative assessment of possible climatic incongruencies between various marine and ice core proxies also depends on establishing a firm temporal connection in the first place. A rigorous assessment of differences between marine and atmospheric records has not been feasible thus far.

[4] Here, we present detailed oxygen isotope records of the relatively shallow-dwelling planktonic foraminiferal species, Globigerina bulloides and Neogloboquadrinapachyderma, from highresolution sediment cores from the subantarctic region of the Southern Ocean's Atlantic sector. We then compare this measure of surface ocean variability with the $\delta \mathrm{D}$ record of ice from Vostok [Jouzel et al., 1987]. This comparison suggests that the foraminiferal $\delta^{18} \mathrm{O}$ data delimits the timing of subantarctic SST changes, despite potential complications for resolving the true amplitude of 




Figure 1. Map showing various core station locations between Africa and Antarctica along with major physical features of the seafloor in the region and physical oceanographic fronts and features described by Belkin and Gordon [1996]. STC corresponds to the subtropical convergence; SAF corresponds to the subantarctic front; and PFZ corresponds to the Polar Front Zone. Details of the core sites are as follows: Site 1089: $40^{\circ} 56^{\prime} \mathrm{S}, 9^{\circ} 54^{\prime} \mathrm{E}, 4621$ meters; TN057-5: $41^{\circ} \mathrm{S}, 9^{\circ} 40^{\prime} \mathrm{E}, 4702 \mathrm{~m}$; RC11-83: $41^{\circ} 36^{\prime} \mathrm{S}, 9^{\circ} 48^{\prime} \mathrm{E}, 4718 \mathrm{~m}$; TN057-21: $41^{\circ} 08^{\prime} \mathrm{S}, 7^{\circ} 49^{\prime} \mathrm{E}, 4981 \mathrm{~m}$;

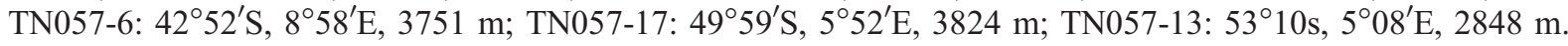

temperature change (such as salinity, ice volume, and foraminiferal habitat). We also show that the broad characteristics of foraminiferal $\delta^{18} \mathrm{O}$ are reproducible in a variety of different pistoncored sedimentary sequences spanning the South Atlantic. Thus the evidence for at least the last 60,000 years justifies a detailed comparison of the South Atlantic foraminiferal $\delta^{18} \mathrm{O}$ record to the ice core data over several glacial cycles.

[5] We present results of an extended comparison, made possible by an Ocean Drilling Program (ODP) borehole, and we illustrate how a synchronization of marine and ice core chronologies might be achieved by aligning the millennial scale features common to both archives. Once this alignment is performed, it allows the construction of a detailed sequence of events in the ocean-atmosphere system, because it then fixes the relationship between deep ocean conditions (in other words, benthic foraminiferal proxies), and the Vostok climate records. This process of aligning the phase of millennial scale variability also leads to a more direct assessment of the relative amplitude of marine and ice core records on orbital timescales. The differences between proxies in this regard may hold clues to their respective controlling influences.

\section{Materials and Methods}

[6] While aboard the R/V Thomas Thompson from January through March 1996 and the R/V JOIDES Resolution from December 1997 through February 1998 for ODP Leg 177, we collected sediment core samples spanning a range of latitudes (roughly between $41^{\circ} \mathrm{S}$ and $53^{\circ} \mathrm{S}$ ) and oceanographic 
Table 1. Accelerator Mass Spectrometry ${ }^{14} \mathrm{C}$ Ages and Calculated Calendar Ages

\begin{tabular}{|c|c|c|c|c|}
\hline Sample Depth, cm & ${ }^{14} \mathrm{C}$ Age, years ${ }^{\mathrm{a}}$ & Error, \pm years & ${ }^{14} \mathrm{C}$ Age & $\begin{array}{c}\text { Calendar Age } \\
\text { (Reservoir Corrected) }^{\mathrm{c}}\end{array}$ \\
\hline \multicolumn{5}{|c|}{ TN057-17 } \\
\hline 293.5 & 8790 & 50 & 7990 & 8600 \\
\hline 635.3 & 10,830 & 50 & 10,030 & 11,550 \\
\hline 746.0 & 12,490 & 60 & 11,690 & 13,000 \\
\hline 831.0 & 13,430 & 60 & 12,630 & 14,700 \\
\hline 1033.5 & 34,150 & 470 & 33,350 & 38,350 \\
\hline \multicolumn{5}{|c|}{ TN057-5 } \\
\hline 70 & 10,070 & 40 & 9,470 & 10,900 \\
\hline 120 & 12,810 & 40 & 12,210 & 14,250 \\
\hline 200 & 15,340 & 50 & 14,740 & 16,900 \\
\hline 350 & 20,030 & 50 & 19,430 & 22,100 \\
\hline 775 & 33,150 & 150 & 32,550 & 37,550 \\
\hline
\end{tabular}

${ }^{\mathrm{a}}$ The ${ }^{14} \mathrm{C}$ dates were obtained from monospecific planktonic foraminiferal samples of left-coiling $N$. pachyderma (core TN057-17) and G. bulloides (TN057-5).

${ }^{\mathrm{b}}$ Subsequent correction is based on the U/Th versus ${ }^{14} \mathrm{C}$ calibration of Bard et al. [1990].

${ }^{\mathrm{c}}$ Inital correction is based on the South Atlantic surface water reservoir age [Bard, 1988]. The assumption of constant reservoir age is potentially compromised by subpolar/subtropical front movements, changes in mode and rate of thermohaline circulation, and other processes that affect the ventilation of the surface ocean. Without direct evidence for these effects, however, we must consider our age estimates to be more uncertain for the earlier part of the record.

conditions in the South Atlantic sector of the Southern Ocean (Figure 1). Sediment core results are also presented from $\mathrm{RC} 11-83$, the details of which are described by Charles et al. [1996]. The core locations are grouped into the southern sites (TNO57-13, TNO57-17), the northern sites (TNO57-5, TNO57-21, RC11-83, and ODP Site 1089), and a middle subantarctic site (TNO57-6). The northern sites are characterized by elevated, but relatively steady sedimentation rates, because they sample a sediment drift deposit. The southern sites were located in the present-day diatomaceous ooze belt and are characterized by highly variable sedimentation rates, ranging from $75 \mathrm{~cm} / \mathrm{ky}$ in interglacial periods to less than $10 \mathrm{~cm} / \mathrm{ky}$ in the glacial episodes. The TNO57-6 site is characterized by much lower sedimentation rates, averaging $3 \mathrm{~cm} / \mathrm{kyr}$; its utility comes from the fact that this single piston core penetrates the last $400 \mathrm{kyr}$ [Hodell et al., 2000].

[7] Our objective was to measure the isotopic composition of the planktonic foraminiferal species that live in the uppermost portions of the water column, as well as those that were consistently abundant in the sediment samples. For these reasons, we chose $N$. pachyderma for the southern sites and $G$. bulloides for the northern sites.
[8] Records from both species are available from TN057-6 [Hodell et al., 2000]. We picked foraminiferal specimens of $N$. pachyderma (leftcoiling) from the 150-250 $\mu \mathrm{m}$ size fraction and G. bulloides from the $>250 \mu \mathrm{m}$ size fraction, at a sample spacing of $5 \mathrm{~cm}$. Isotopic analyses for TN057-13, TNO57-6, and MIS Stages 8-12 of Site 1089 were performed at the University of Florida. All other measurements were made at the Scripps Institution of Oceanography (SIO). For both laboratories, the long-term precision $(1 \sigma)$ of a National Bureau of Standards NBS-19 standard was better than $0.1 \%$ for $\delta^{18} \mathrm{O}$ over a period of several years when the samples were run.

[9] For several marine records (TNO57-13, TNO57-17, TN057-5 and RC11-83), chronologies for the upper sections were developed through radiocarbon dating. The details for TNO57-13 [Kanfoush et al., 2000] and RC11-83 [Charles et al., 1996] are presented elsewhere, while those for TNO57-17 and TN057-5 are presented here (Table 1). The chronology for the last $60 \mathrm{ky}$ of TNO57-21, ODP Site 1089, and TNO57-6 records comes through optimization of the correlation of both planktonic and benthic $\delta^{18} \mathrm{O}$ time series to those from nearby benchmark cores that are dated by radiocarbon (such as RC11-83.) To 


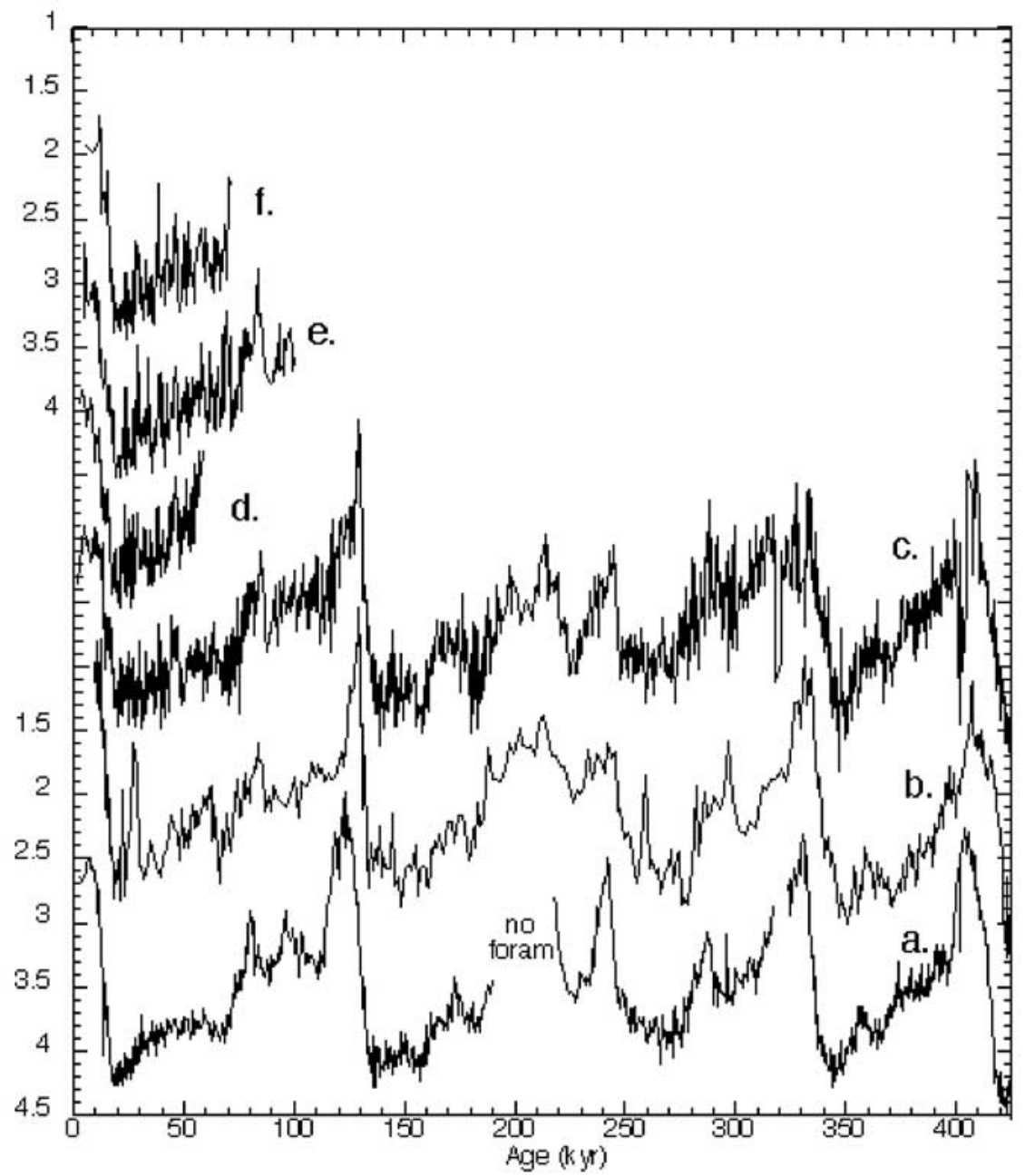

Figure 2. $\delta^{18} \mathrm{O}$ (in \%o units) stratigraphy of the cores from the northern and central subantarctic zone. ODP Site 1089, Cibicidoides spp. [from Hodell et al., 2001] (curve a), TN057-6, G. bulloides [from Hodell et al., 2000] (curve b), Site 1089, G. bulloides (this study) (curve c), TN057-5, G. bulloides [from Channell et al., 2000] (curve d), TN057-21, G. bulloides [Mortyn, 2000] (curve e), RC11-83, G. bulloides [from Charles et al., 1996] (curve f). Curves $b$ through e have been offset from the top scale by $+4,+3,+2$, and +1 , respectively.

extend the chronologies past the limits of radiocarbon dating,we correlated benthic foraminiferal $\delta^{18} \mathrm{O}$ records from RC11-83 and ODP Site 1089 with the stacked and orbitally tuned benthic foraminiferal $\delta^{18} \mathrm{O}$ record of Martinson et al. [1987] for MIS 1-8, and with the ODP Site 677 benthic $\delta^{18} \mathrm{O}$ record for MIS 8-12 [Shackleton et al., 1990]. Over the intervals that lack detailed structure for correlation (such as marine isotope stage 3), we assume constant sedimentation rates between more widely spaced tie points, a reasonably valid assumption at these sites [Hodell et al., 2001]. We estimate that the precision of correlation, and therefore transferral of the orbitally tuned chronology to Site 1089 , is likely to be better than \pm 2 ky throughout the length of the record, though this error assessment is subjective. One departure from the Martinson et al. [1987] chronology is the interval from the LGM to the present, for which we used radiocarbon chronology converted to calendar years. In this regard, we note that the SPECMAP chronology of Martinson et al. [1987] is not strictly "orbitally tuned" at its beginning and end. The chronology for TNO57-6 along the length of the core comes from correlating planktonic and benthic isotopic records to Site 1089 (and, therefore, the chronology for this core is tied to that of Site 1089). All the $\delta^{18} \mathrm{O}$ data is displayed in Figure 2, 


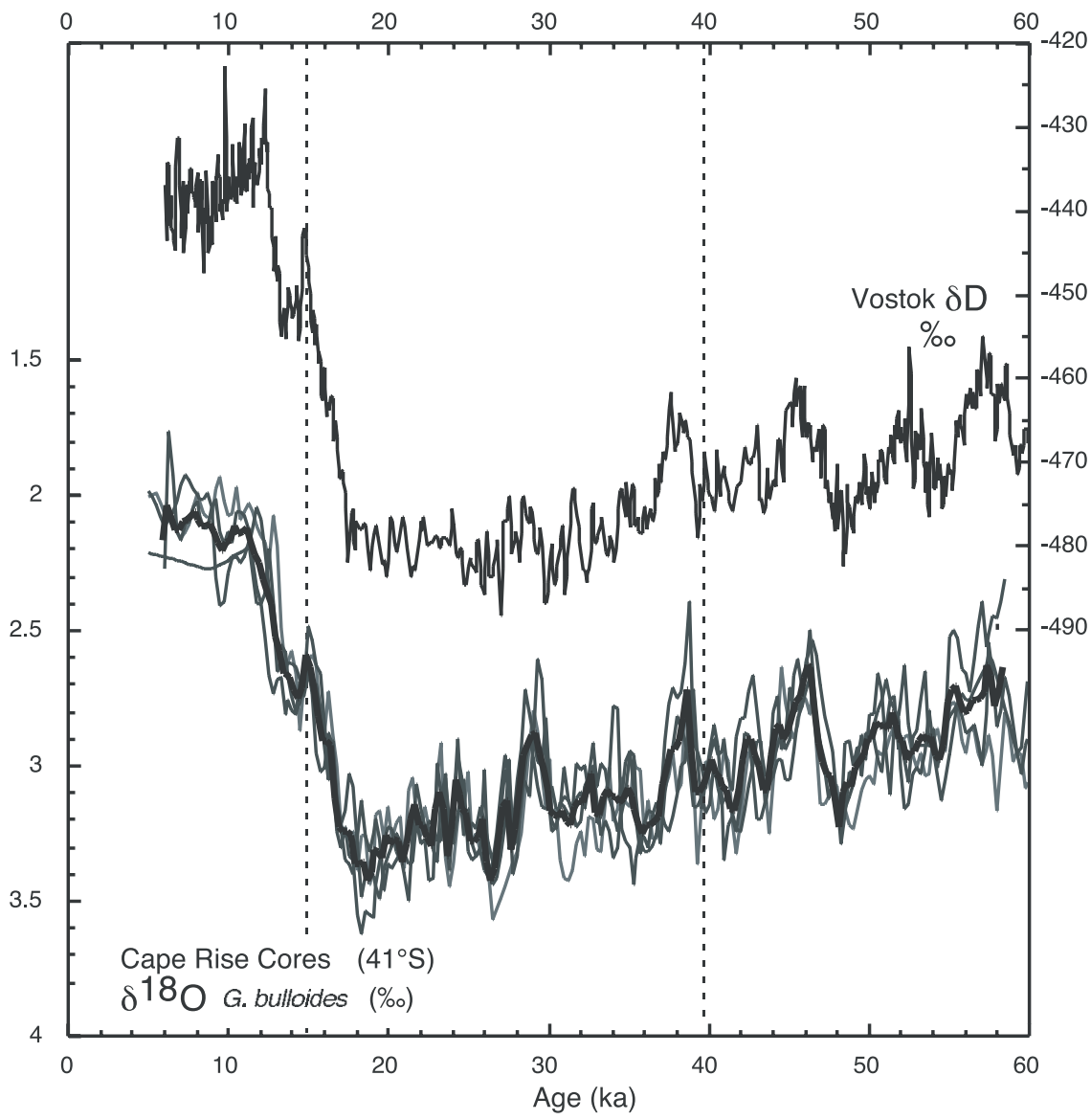

Figure 3. G. bulloides $\delta^{18} \mathrm{O}$ records from the northern subantarctic cores, with the stacked record (heavy line) superimposed, compared with the Vostok deuterium record covering the same time interval. The chronology for Vostok follows that of Blunier et al. [1998] and Bender et al. [1999]. For an illustration of phase, dashed lines denote the onset of the "Antarctic Cold Reversal" at about $14 \mathrm{kyr}$ and the peak expression of the "Laschamp" geomagnetic event at about $40 \mathrm{kyr}$.

already converted to timeseries form, but the actual data not published previously is available on the ODP data server [Hodell et al., 2003].

\section{Results}

\subsection{The Last 60,000 Years}

[10] We concentrate initially on the last $60 \mathrm{ky}$ to demonstrate that the subsequent comparisons for the past $400 \mathrm{ky}$ are meaningful. Figure 3 shows the details of our planktonic foraminiferal $\delta^{18} \mathrm{O}$ results from each of the four northern sites (TNO57-5, TNO57-21, RC11-83, and ODP Site 1089) compared against the $\delta \mathrm{D}$ profile from the Vostok ice core. For this comparison, we chose the Blunier et al. [1998] timescale for the upper $40 \mathrm{ky}$ and the Bender et al. [1999] timescale for the 40-60 ka interval of Vostok. Both of these ice core timescales operate on the principle of correlating atmospheric $\mathrm{CH}_{4}$ or $\delta^{18} \mathrm{O}\left(\mathrm{O}_{2}\right)$ measurements between ice cores in both hemispheres, in effect transferring the GISPII or GRIP chronology to Vostok. However, the published Blunier et al. [1998] timescale for Vostok only extends to $50 \mathrm{ka}$, necessitating the use of two different chronologies. (We also adjusted for the slight difference in the two ice core timescales in the interval of overlap to make the spliced chronology.)

[11] One would expect a high degree of similarity in $\delta^{18} \mathrm{O}$ between the deep sea sediment records because (1) the sites are all within similar oceanographic regimes, (2) all of the results were generated in the same laboratory (SIO), (3) all cores contain consistent abundance of $G$. bulloides, and 
(4) the average sedimentation rate of all the cores is roughly comparable. Thus we combined the G. bulloides $\delta^{18} \mathrm{O}$ data from the northern sites into an interpolated stack for detailed comparison against the $0-60 \mathrm{ka}$ Vostok $\delta \mathrm{D}$ record (Figure 3). The period from $6.0-58.5$ ka represents the maximum duration for which data were available from each of the four cores, and the chronology below the limits of radiocarbon control essentially comes from extrapolation of sedimentation rates from the closest anchor points.

[12] The resultant "subantarctic stack" bears obvious similarity with the Vostok ice core record. Perhaps the most direct connection can be drawn between the so-called Antarctic Cold Reversal (ACR) that seems to appear in both the marine and ice core records at about $14 \mathrm{ka}$. However, other millennial features are also closely aligned in the marine and ice core records. For example, abrupt excursions toward lower foraminiferal $\delta^{18} \mathrm{O}$ occur at approximately $51 \mathrm{ka}, 46 \mathrm{ka}, 39 \mathrm{ka}$, and $29 \mathrm{ka}$. These features correspond closely with the ice core evidence for warming over the Antarctic interior [Blunier and Brook, 2001]. This comparison suggests that the climate signal of Vostok is indeed embedded in G. bulloides $\delta^{18} \mathrm{O}$ data sets from the subantarctic provided, of course, that all possible sources of error (including core sampling, chronology, foraminiferal population biases, instrumental error) can be minimized.

[13] The southern site cores allow spot checks on the correlations suggested by the northern subantarctic $\delta^{18} \mathrm{O}$ records. The most complete comparison involves the last deglaciation, and the "Antarctic Cold Reversal" event in particular. The N. pachyderma $\delta^{18} \mathrm{O}$ records from both TNO57-13 and TNO57-17 are shown in Figure 4. The two foraminiferal records display many of the same features from the last glacial period into the deglaciation, and throughout the Holocene. The profiles differ in mean value from one another by approximately $0.5 \%$, as a result of cooler SSTs at the more southern site (hence higher $\delta^{18} \mathrm{O}$ ). Both profiles are also significantly offset from their northern subantarctic counterparts for the same reason. The southern sites are less continuous, because the flux of all microfossils, including $N$. pachyderma, decreases during the cold intervals and because the foraminifera are at times completely diluted by diatoms during warmer intervals. Nevertheless, the distinct millennial features of the Vostok $\delta \mathrm{D}$ record are also present in the marine $\delta^{18} \mathrm{O}$ record from our southern sites; for example, the interstadial event at approximately $38 \mathrm{ka}$ and the expression of the ACR at approximately $14 \mathrm{ka}$ stand out prominently. One difference between the northern and southern marine sequences is that the period immediately following the ACR is characterized by a $\delta^{18} \mathrm{O}$ decrease that is stronger in the south than in the north $(1 \%$ o versus $0.6 \%$, respectively). While the amplitude of $\delta^{18} \mathrm{O}$ change is different over some excursions, the major events of the last deglaciation are synchronous in all of our subantarctic cores, within the errors of the radiocarbon dating constraints. Furthermore, the various independent radiocarbon chronologies suggest that the timing of these $\delta^{18} \mathrm{O}$ excursions from $53-40^{\circ} \mathrm{S}$ is indistinguishable from those in the Vostok ice core $\delta \mathrm{D}$ record, provided that a GISP/GRIP-like chronology is used for Vostok [e.g., Blunier et al., 1998].

[14] Still, the uncertainties in radiocarbon chronology (including the possibility of reservoir age changes [Goldstein et al., 2001]) are too large prior to the last deglaciation to conclude definitively that any particular excursion in the marine records is synchronous with its apparent ice core counterpart. Thus independent confirmation of such synchroneity is required. At specific points during MIS Stage 3, the comparison between magnetic paleointensity recorded in the marine sediments [Channell et al., 2000; Stoner et al., 2003] and the Vostok ${ }^{10}$ Be record (cited in Mazaud et al. [1994]) provides this confirmation. Sharp spikes in both records suggest that there were significant excursions in the Earth's magnetic field at approximately $40 \mathrm{ka}$ (the so-called Laschamp event) and at approximately $65 \mathrm{ka}$. These excursions thus serve as discrete chrono-horizons that can be correlated in marine and ice core archives. For our purposes here, the essential observation is that the process of aligning the phase of foraminiferal $\delta^{18} \mathrm{O}$ and Vostok $\delta \mathrm{D}$ according to the assumption of climatic synchroneity does not violate the requirement that the marine and ice core proxies for magnetic field 


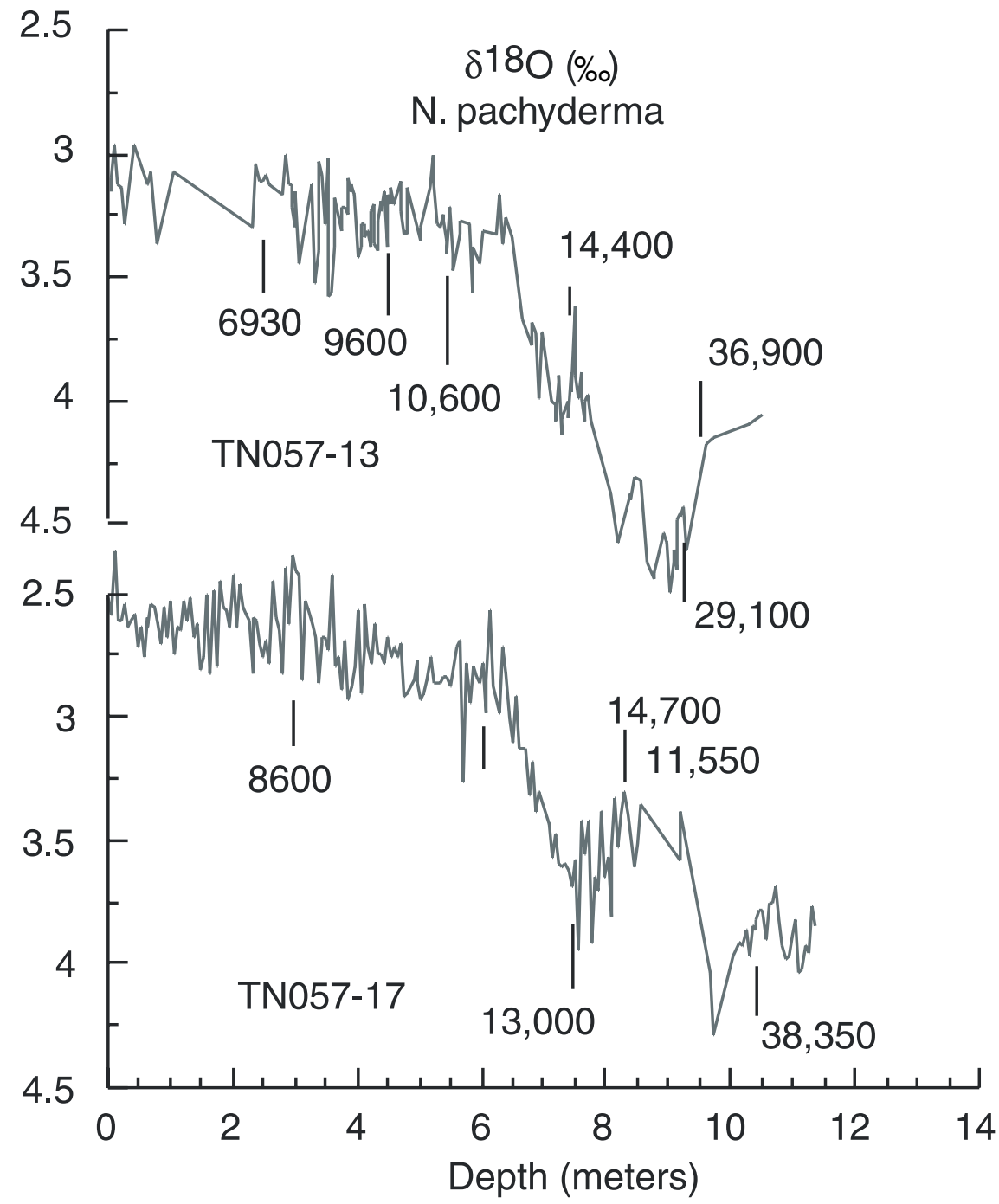

Figure 4. Radiocarbon stratigraphy of the two $\delta^{18} \mathrm{O}$ records from cores south of the present polar front, both from N. pachyderma. The AMS ${ }^{14} \mathrm{C}$ dates shown have been converted to calendar years (see Kanfoush et al. [2000] and Table 1 for details). Note the close correspondence between the age of the "Antarctic Cold Reversal" at about 14 ka in these cores with the apparent ice core equivalent.

behavior must also be synchronous (Figure 5). Thus the subantarctic foraminiferal $\delta^{18} \mathrm{O}$ and Vostok $\delta \mathrm{D}$ millennial oscillations must be coeval, for at least those specific intervals characterized by large magnetic field excursions. It is significant that the total error on this assessment of stratigraphic correlation (as opposed to absolute chronology) is on the order of several hundred years and therefore does not exceed the duration of the millennial scale temperature events themselves.

\subsection{The Last 400,000 Years}

[15] We assume, by extension and without attribution of a specific physical mechanism, that the degree of marine core/ice core correlation apparent in the $60 \mathrm{ky}$ interval should also apply to the lower portions of the records. Therefore to synchronize the Vostok $\delta \mathrm{D}$ chronology to that of an orbitally tuned marine chronology over four glacial cycles, we combined the "subantarctic stack" data of Figure 3 with the longer $G$. bulloides $\delta^{18} \mathrm{O}$ record from ODP Site 1089.

[16] We adjusted the Petit et al. [1999] chronology iteratively to achieve maximum correlation between Vostok $\delta \mathrm{D}$ and the Site 1089 planktonic foraminiferal $\delta^{18} \mathrm{O}$ record. This approach yields a new chronology for the Vostok ice core (Figure 6) that is significantly different from the previous 


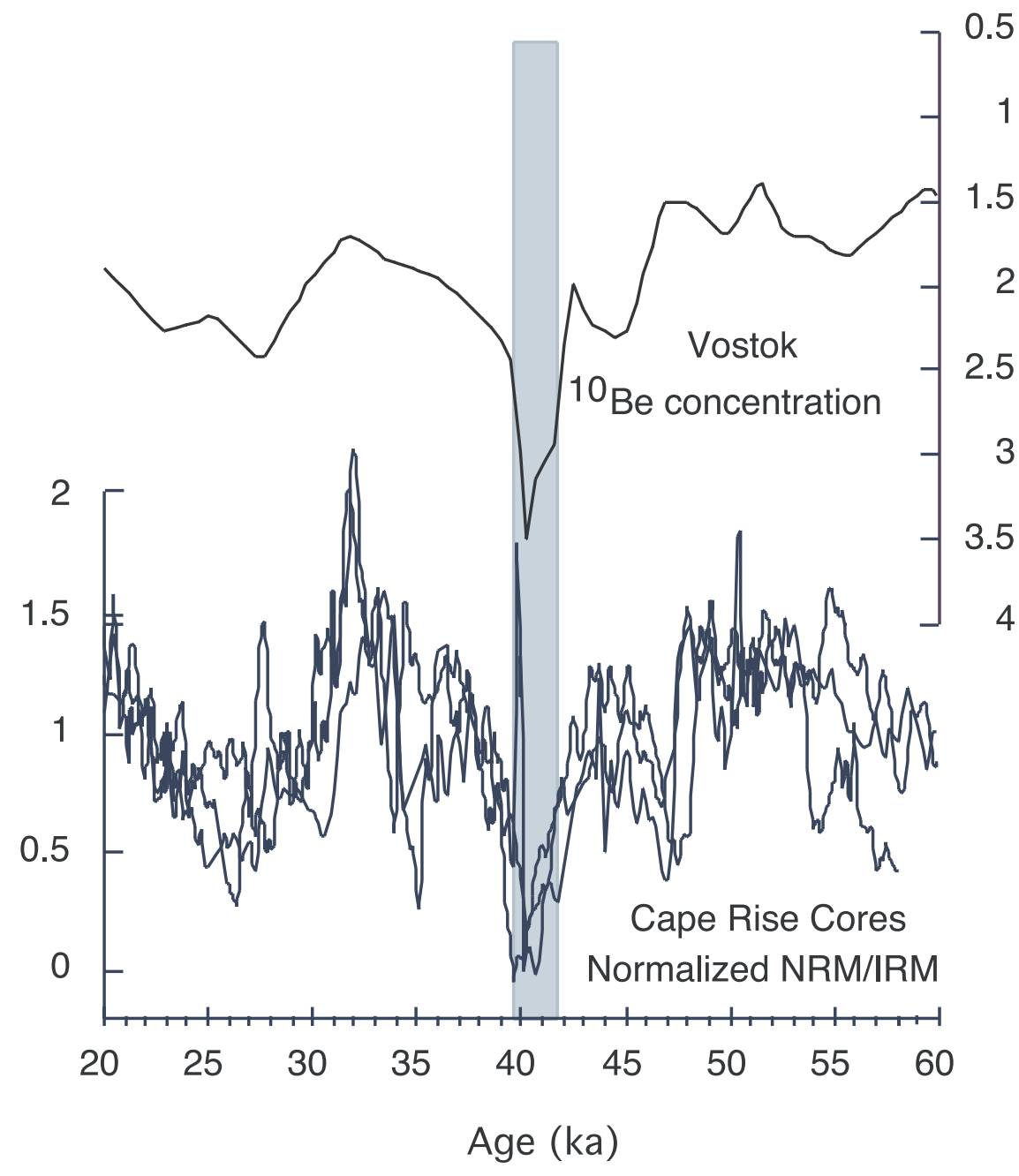

Figure 5. The record of magnetic paleointensity in the northern subantarctic cores (TNO57-4, 5, and 21 from Channell et al. [2000]) compared with the variations in ${ }^{10} \mathrm{Be}$ in Vostok [from Mazaud et al., 1994]. The chronologies for the sediment record and the ice cores are the same as in Figure 3. The magnetic paleointensity spike in all the sediment cores and the ${ }^{10} \mathrm{Be}$ spike in Vostok fall within the same phase of the millennial scale climate oscillation expressed in both marine and ice core records.

published version (GT4 timescale). We adjust the ice chronology to the marine chronology, rather than the converse strategy, because the orbital tuned marine chronology rests on a better known and widely used framework of assumptions than that for the ice core flow modeling [Petit et al., 1999]. Also, the sedimentation rates for the marine core are relatively constant. Overall, the marine/ ice core correlation that can be achieved through this subjective approach is quite high $(\mathrm{R}=0.76)$, but it depends completely on the ability to recognize distinctive millennial scale events common to both records. In this respect, our (subjective) confidence in age assignments for the ice core decreases considerably in the older part of the record, where the resolution of the ice core decreases and where carbonate dissolution affects the quality of the foraminiferal record [Hodell et al., 2001]. One could certainly take issue with our chronological adjustments in any given interval, and, therefore, we view this approach as simply a first illustration of how a marine chronology can be transferred to Vostok in detail. The accuracy of the results would no doubt improve if we were able to create a "stacked" foraminiferal record over several glacial cycles using a variety of sedimentary sequences, instead of that from just one site. 

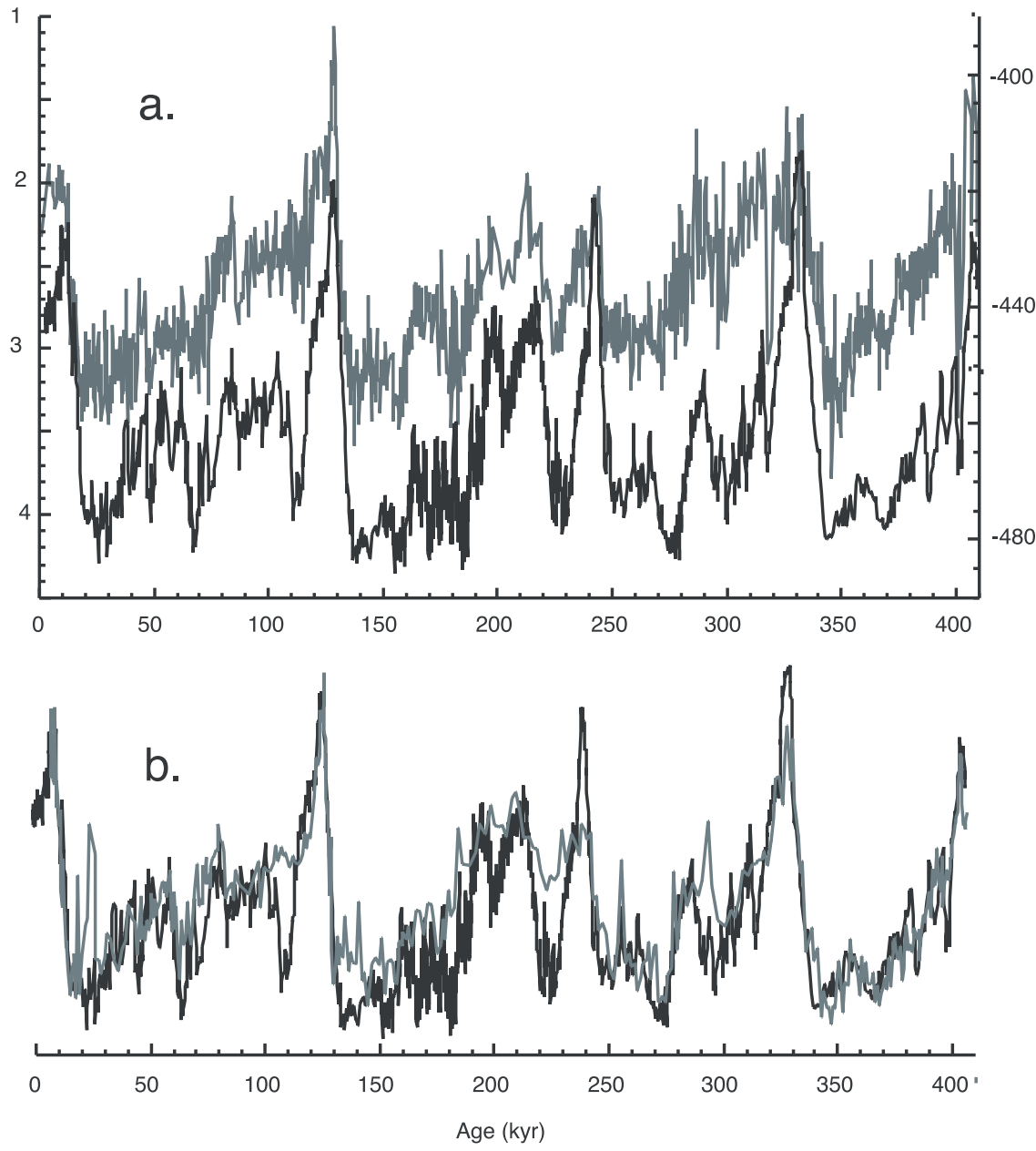

Figure 6. (a) Comparison between the Vostok deuterium record (taken from Vimeux et al. [2001]) and G. bulloides $\delta^{18} \mathrm{O}$ (gray) from ODP Site 1089 over four glacial cycles. The Vostok chronology was adjusted iteratively (and subjectively) to achieve maximum correlation with the Site 1089 record. (b) One independent, but lower- resolution cross-check on this synchronization comes from the $\delta^{18} \mathrm{O}$ record of TN057-6 (gray) [from Hodell et al., 2000].

[17] The results from the lower-resolution core TNO57-6 provide at least a rough crosscheck on our "wiggle matching" approach using Site 1089. Though the millennial scale features are muted in this core, the changes in foraminiferal $\delta^{18} \mathrm{O}$ are well-correlated with those of Vostok $\delta \mathrm{D}$. This result is not surprising, given that we tuned the TNO57-6 chronology to maximize isotopic correlations with Site 1089; but it does suggest that our strategy is consistent among South Atlantic subantantarctic marine cores for the last 400,000 years, just as it is for the last 60,000 years.

[18] For the purpose of this correlation exercise, we made no attempt to remove the more slowly varying seawater isotopic signal (ice volume effect) from the $G$. bulloides $\delta^{18} \mathrm{O}$ record. One indication that the oscillations in the planktonic $\delta^{18} \mathrm{O}$ reflect surface water variability alone is that the benthic foraminiferal $\delta^{18} \mathrm{O}$ does not show the same abrupt fluctuations in the glacial period (Figure 2). As a result, normalizing the planktonic foraminiferal $\delta^{18} \mathrm{O}$ by subtracting the benthic signal would not alter our basic approach or conclusions derived from the millennial band.

[19] With the exception of two specific intervals (the penultimate deglaciation and early MIS 11), our indirect approach toward orbital tuning of the Vostok ice chronology yields results broadly similar to those derived from the direct orbital tuning of the Vostok gas chronology using 
$\delta^{18} \mathrm{O}$ atm [Petit et al., 1999; Shackleton, 2000]. With several more prominent exceptions during the glacial stages (the millennial scale excursions in MIS 2-4 and MIS 6), our chronology is also consistent with the results of a separate tuning exercise of the Vostok ice chronology using the Vostok deuterium record [Waelbroeck et al., 1995]. However, one notably distinct aspect of our chronology is the duration of the last interglacial period. In our chronology, the duration of this interval (defined from peak glacial episodes on either side of the last interglacial) in the Vostok $\delta \mathrm{D}$ record is almost exactly $23 \mathrm{ky}$, whereas it is much longer (30 to $40 \mathrm{ky}$ ) in the other chronologies. This result essentially derives from the structure of the Site 1089 benthic foraminiferal record and its projection onto the SPECMAP benthic stack [Martinson et al., 1987], which establishes our timescale for the marine surface climate proxies.

[20] The chronological adjustments using the millennial scale features affect the determination of spectral properties of Vostok ice core proxies in the orbital band. The most obvious effect of our modification of previous timescales is the transferral of power in the $\delta \mathrm{D}$ record from the lower frequencies into the $23 \mathrm{ky}$ band and its harmonics. As with $\delta \mathrm{D}$, the implementation of our chronology also significantly enhances the 23 ky power in $\delta^{18} \mathrm{O}$ atm, relative to the GT4 [Petit et al., 1999] timescale. Our results in this respect essentially parallel those of Shackleton [2000], as one might predict from the general similarity of the two chronologies. In fact, the resulting spectra are similar enough that we need not show them here. However, the implied duration of the last interglacial period in our work results in an especially sharp $23 \mathrm{ky}$ spectral peak in the power spectrum of the Vostok deuterium record.

\subsection{Deuterium Excess and the Northern Subantarctic Isotopic Records}

[21] In adjusting the chronology of Vostok, we make the assumption that the timing of millennial scale subantarctic $\delta^{18} \mathrm{O}$ changes and air temperature changes over Antarctica is the same. However, we make no assumption concerning the relative amplitudes of change in the marine/ice core proxy records. In fact, from simple visual comparison, it is obvious that the foraminiferal $\delta^{18} \mathrm{O}$ record diverges from the ice core record on orbital timescales. For example, the prominent minima in the Vostok $\delta \mathrm{D}$ at the beginning of glaciation events are not present in the marine record. We can quantify this difference to form a continuous time series by normalizing both proxy records and by taking the residual (though we cannot distinguish whether the anomalies in the normalized difference reflect a bias in the marine record (with respect to Vostok) in warm or cold intervals, or both.)

[22] Potential clues to the origin of the foraminiferal $\delta^{18} \mathrm{O} /$ ice core $\delta \mathrm{D}$ differences come from the fact that this time series resembles the deuterium excess fluctuations in the Vostok core [Vimeux et al., 1999, 2001]. There are occasional mismatches in the amplitude of the residual curve and the deuterium excess-perhaps to be expected, given the derivation of these second order variables-but the timing of the major excursions is essentially the same (Figure 7). The marine $\delta^{18} \mathrm{O}$ and Vostok $\delta \mathrm{D}$ show the greatest difference early in the glaciation stage (e.g., Stage 5d) and the smallest difference during the deglaciations; these changes are coincident, respectively, with the maximum and minimum anomalies in deuterium excess. It is significant that the best correlation between the marine/ice residual and deuterium excess occurs in the uppermost portion of the records that are anchored by independent chronologies. Thus the correspondence between these variables cannot be strictly an artifact of the chronological assumptions.

[23] The pattern of variability is, to a large extent, also characteristic of the "common" carbon isotope signal in subantarctic planktonic foraminiferal records from the circum-subantarctic [Ninnemann and Charles, 1997]. Planktonic foraminiferal $\delta^{13} \mathrm{C}$ has a complex spatial expression in the subantarctic and is no doubt influenced by processes other than those affecting the surface ocean. Therefore one wouldn't expect all carbon isotope records to share the same phase relationship with the ice core proxies. However, for cores such as TN057-6 and E33-22 (subantarctic South Pacific), the correlation 

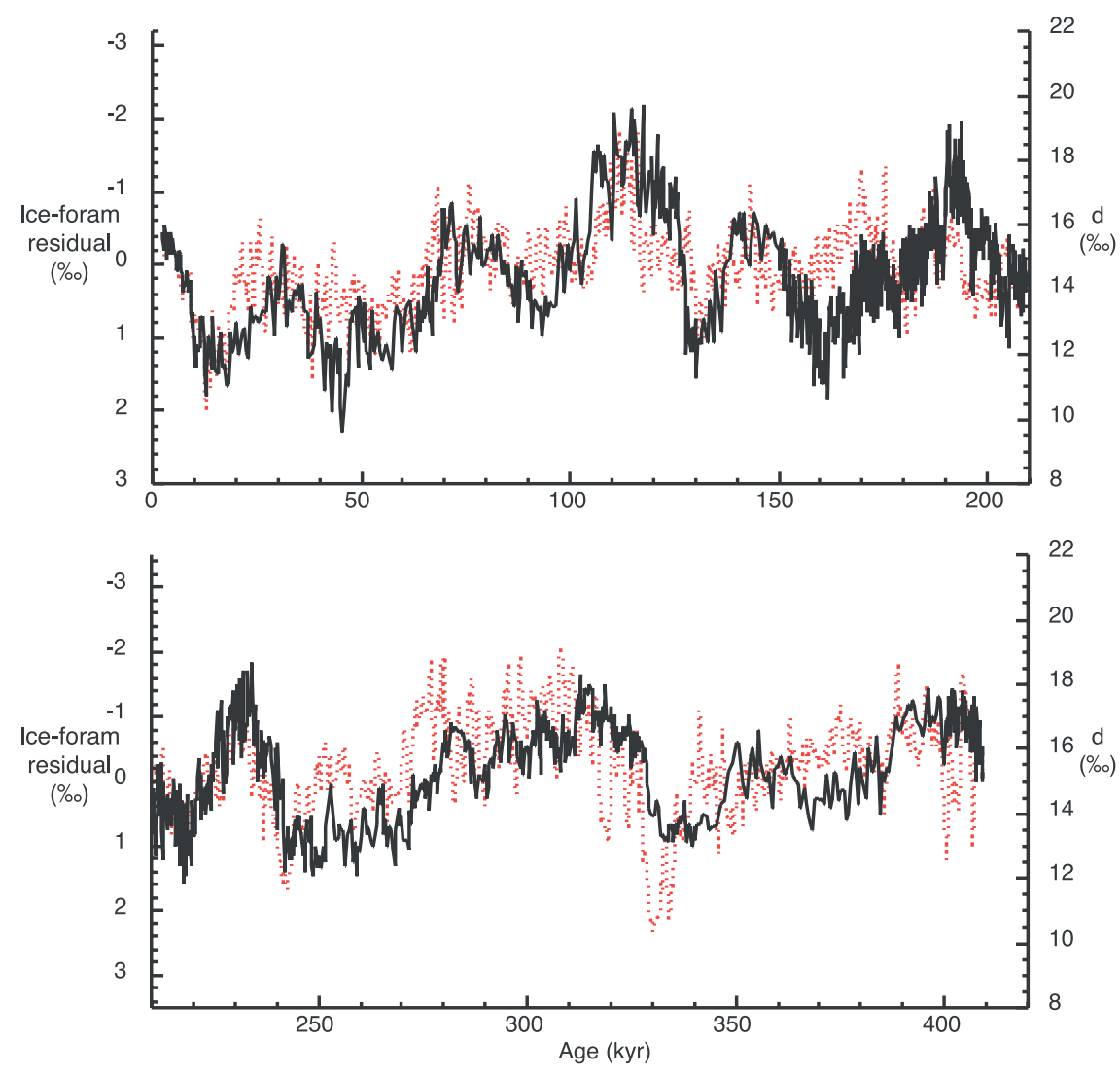

Figure 7. The residual amplitude between the normalized Vostok $\delta \mathrm{D}$ record and the normalized G. bulloides $\delta^{18} \mathrm{O}$ record (dashed red line), plotted with the Vostok deuterium excess (black). This comparison assumes the Site 1089synchronized chronology for Vostok (i.e., that shown in Figure 6). The deuterium excess data is from Vimeux et al. [2001].

between planktonic foraminiferal $\delta^{13} \mathrm{C}$ and Vostok deuterium excess at zero phase is quite strong (Figure 8)-even for Stages 8-11, where deuterium excess is characterized by a seemingly different response to orbital forcing than for the last 150,000 years [Vimeux et al., 2001]. For example, considering TN057-6 $\delta^{13} \mathrm{C}$ and Vostok deuterium excess, there is strong coherency throughout the records in all the orbital frequencies (over $80 \%$ of the variance is shared for the 23,41 , and $100 \mathrm{kyr}$ periods), and, while there is a slight phase offset between the records in the $41 \mathrm{kyr}$ band, there is no significant phase difference in the other bands.

[24] Because these various independent comparisons all demonstrate a strong connection between the conditions of the subantarctic surface ocean and the water isotopes (deuterium and deuterium excess) in Vostok, they may also serve as additional constraints on the marine core/ice core synchronization process. For example, if the marine and ice core records were grossly miscorrelated, then the residual between foraminiferal $\delta^{18} \mathrm{O}$ and Vostok $\delta \mathrm{D}$ would be mere noise. Similarly, the recognition of a $\delta^{13} \mathrm{C} /$ deuterium excess link might help optimize the marine/ice stratigraphic alignments in some intervals where the foraminiferal $\delta^{18} \mathrm{O}$ signal lacks a clear structure.

\subsection{Sequence of Events Over Terminations}

[25] Aside from issues of absolute chronology, a more unique consequence of making an explicit tie between the surface ocean $\delta^{18} \mathrm{O}$ and the Vostok $\delta \mathrm{D}$ records is that it automatically fixes the temporal relationship between other (independent) proxy variables contained in the same marine and ice core records. This approach already has been applied to the millennial scale variability of the last glacial cycle [Charles et al., 1996; Ninnemann 


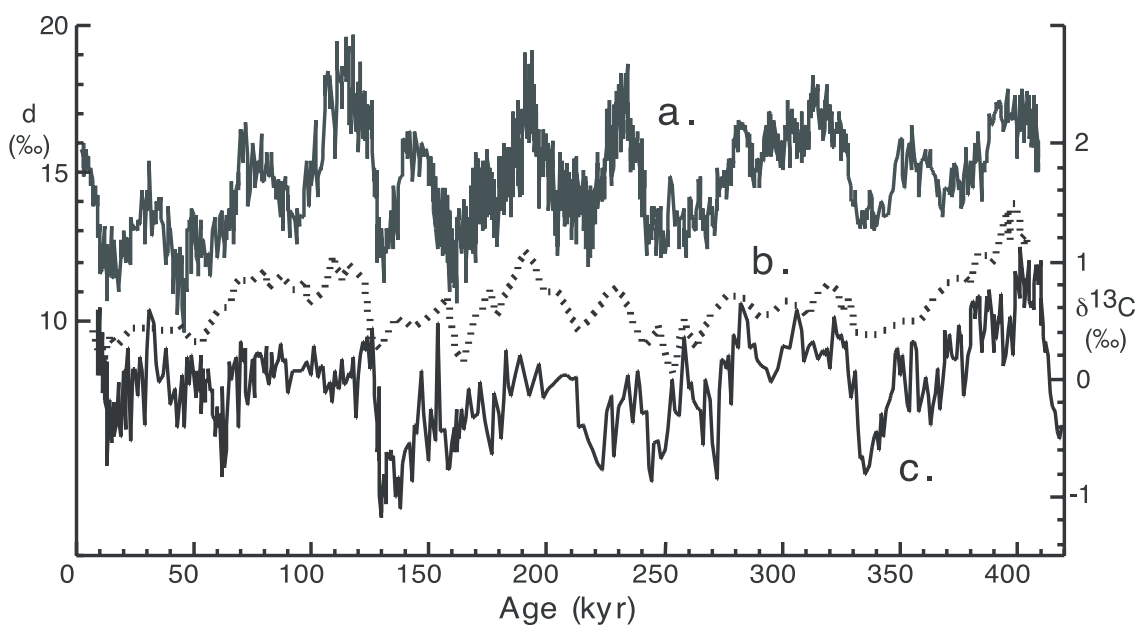

Figure 8. Comparison between the Vostok deuterium excess (curve a) and planktonic foraminiferal $\delta^{13} \mathrm{C}$ in core E33-22 (curve b) in the subantarctic Pacific; and TN057-6 in the subantarctic Atlantic (curve c) using the Site 1089synchronized chronology for Vostok. Cross spectral analysis indicates strong coherency in all orbital frequencies and suggests that marine/ice phase offsets are localized to the $41 \mathrm{kyr}$ band. Note that the chronology for TN057-6 is the same as that applied to the $\delta^{18} \mathrm{O}$ record in Figure 6b. The deuterium excess data is from Vimeux et al. [2001], the E33$228^{13} \mathrm{C}$ comes from Ninnemann and Charles [1997], and the TN057-6 record comes from Hodell et al. [2000].

et al., 1999], but we elaborate here on the particularly important case studies: the events surrounding the deglaciation events (Terminations).

[26] Figure 9 shows the relative timing of various ocean-atmosphere proxies over Termination II that results from optimizing the correlation between planktonic $\delta^{18} \mathrm{O}$ in Site 1089 and the $\delta \mathrm{D}$ of ice in Vostok. Clearly, the respective warm extremes in planktonic foraminiferal $\delta^{18} \mathrm{O}$ and Vostok $\delta \mathrm{D}$ were reached several thousand years before the minimum in benthic foraminiferal $\delta^{18} \mathrm{O}$, an observation often described as a Southern Ocean temperature "lead" with respect to global ice volume (e.g., Hays et al. [1976] and many others). Yet an equally important feature of our comparison here is that it gives the appearance of little to no lag between the major benthic foraminiferal isotopic shifts toward interglacial conditions and the ice core $\delta \mathrm{D}$ shifts toward warmer temperatures over the penultimate deglaciation. If one compares the midpoints of the deglaciation in these deepwater and atmospheric proxies (one way to avoid the inherent ambiguity of the terms "lead" and "lag"), they do not differ by more than 1500 years-for all but benthic foraminiferal $\delta^{18} \mathrm{O}$, the age of these midpoints is indistinguishable from one another.
Furthermore, there is no discernable sequence in the timing of the first monotonic change to interglacial conditions in all variables.

[27] These observations help place limits on the phase relationships between Antarctic ice core proxies and sea level (ice volume), though they do not provide precise constraints. It is presently impossible to partition the benthic foraminiferal $\delta^{18} \mathrm{O}$ change cleanly into a temperature component and an ice volume effect. However, there are general limits to deep ocean temperature variability-glacial temperatures could not have been lower than the seawater freezing point-and therefore we can at least establish a maximum temperature effect of about $0.8 \%$ o $\left(\sim 3^{\circ} \mathrm{C}\right)$ over deglaciation events. If we assume that the deep ocean warmed entirely before ice volume began to decrease, then the point at which benthic foraminiferal $\delta^{18} \mathrm{O}$ decreased by $0.8 \%$ also marks the initial decrease of deep seawater $\delta^{18} \mathrm{O}\left(\delta^{18} \mathrm{O}\right.$ s.w. or ice volume effect). This assumption, combined with our synchronization approach, establishes an absolute maximum of $\sim 2.5$ kyr lag between the midpoint of the Vostok $\delta \mathrm{D}$ shift and the midpoint of $\delta^{18} \mathrm{O}$ s.w. shift over the penultimate deglaciation.

[28] The comparison of the Southern Ocean benthic foraminiferal $\delta^{18} \mathrm{O}$ with the $\delta^{18} \mathrm{O}$ atm in 


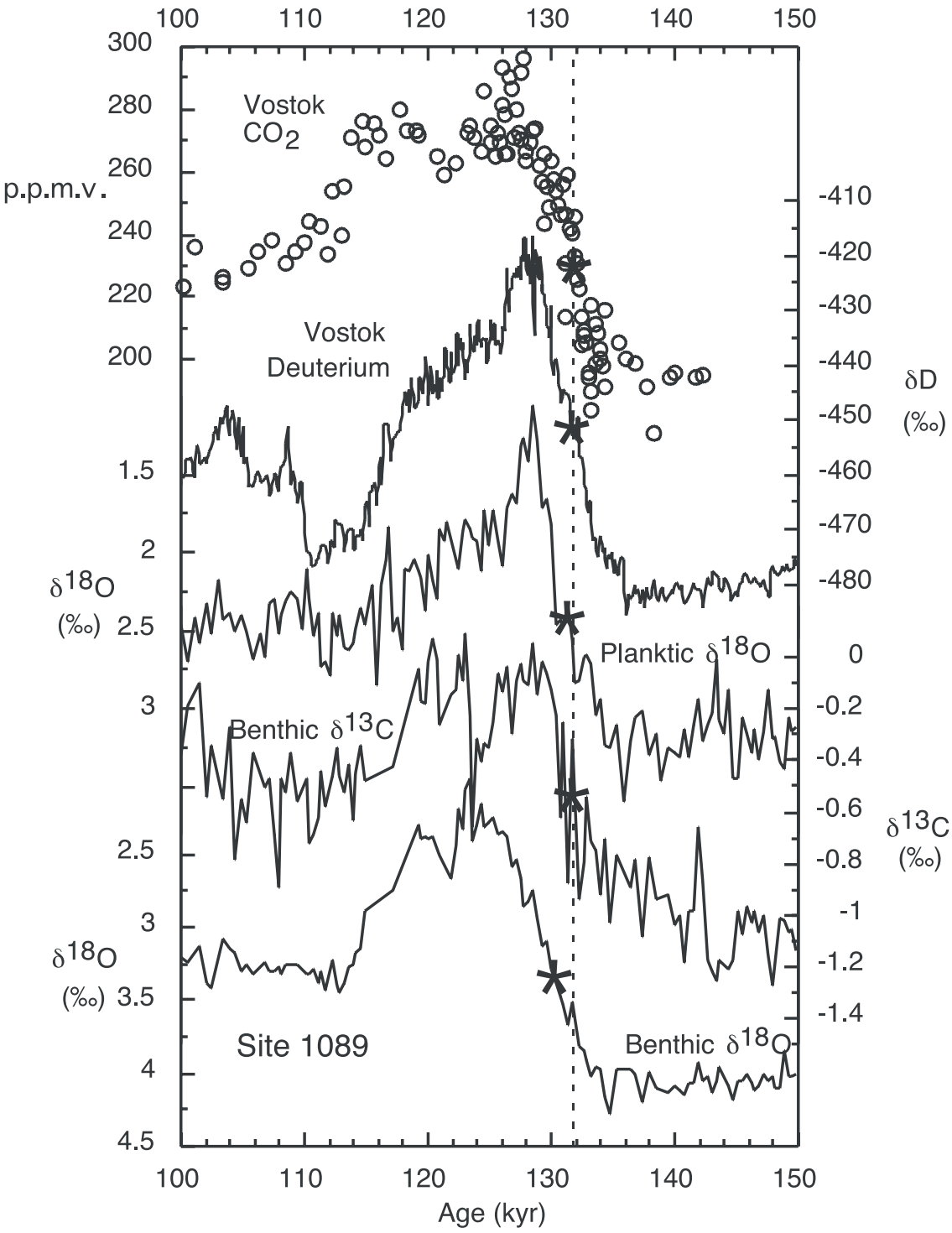

Figure 9. Sequence of events in various proxies of the ocean atmosphere system over the penultimate deglaciation, resulting from the assumption that the millennial-scale features of the Vostok $\delta \mathrm{D}$ and Site 1089 G. bulloides $\delta^{18} \mathrm{O}$ records are synchronous. The midpoints of the deglaciation in all proxies are marked by an asterisk. The deuterium data were taken from Petit et al. [1999], while the atmospheric $\mathrm{CO}_{2}$ data were taken from Fischer et al. [1999].

the Vostok ice core suggests that the minimum lag of the midpoint of the $\delta^{18} \mathrm{O}$ atm change with respect to the midpoint of $\delta^{18} \mathrm{O}$ s.w. change was, on average, about $2 \mathrm{kyr}$ over the Terminations (Figure 10). A more reasonable estimate for this lag (considering the physical improbability that the deep ocean would warm entirely to interglacial levels before the excess glacial ice even began to melt) would be 3 to $4 \mathrm{ky}$ for the Terminations of the Late Pleistocene. Because the $\Delta$ age of gas-ice introduces an additional variable (with uncertainties that are possibly $>1$ kyr [Bender et al., 1999], and because there are fewer total measurements currently available, any comparisons between $\delta^{18} \mathrm{O}$ atm with the marine records are less certain, despite the fact that we could conceivably align the marine $\delta^{18} \mathrm{O}$-ice core $\delta \mathrm{D}$ stratigraphy to within several hundred years. Nevertheless, taking the best current estimates of $\Delta$ age of gas-ice, our results are incompatible with the interpretation of $\delta^{18} \mathrm{O}$ atm as a sea level proxy that lags true ice volume at all times by only $1 \mathrm{kyr}$. 

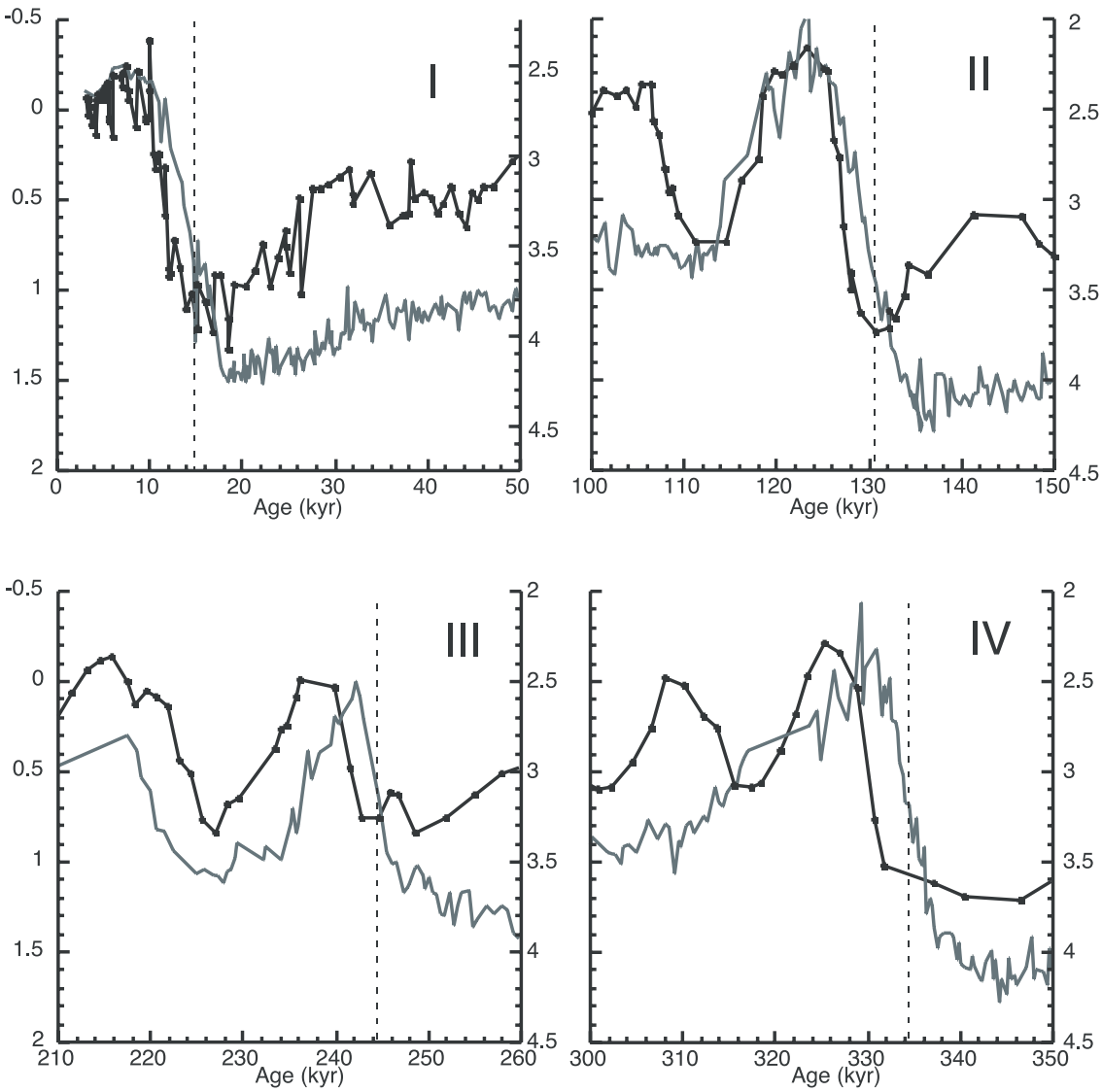

Figure 10. Comparison between the Site 1089 benthic foraminiferal $\delta^{18} \mathrm{O}(\%$, right-hand scale) and the Vostok $\delta^{18} \mathrm{O} \mathrm{atm}$. Left-hand scale is the same for all plots. $\mathrm{O}_{2}$ anomaly (\%o, left-hand scale) over several terminations, assuming the chronology in Figure 6 while taking the $\mathrm{O}_{2}$ data and gas age-ice age difference given in Petit et al. [1999]. The dashed line represents the latest possible time for the initiation of deglaciation, based on the assumption that the temperature influence on the benthic foraminiferal $\delta^{18} \mathrm{O}$ can be no more than about $0.8 \%$ over the terminations.

This conclusion is relevant if $\delta^{18} \mathrm{O}$ atm is to be used to define glacial-interglacial transitions in ice core records alone [e.g., Broecker and Henderson, 1998].

[29] Perhaps most importantly, our marine/ice core alignment sets the phase of atmospheric $\mathrm{CO}_{2}$ variations with respect to the deep ocean. For this purpose, we can take benthic foraminiferal $\delta^{13} \mathrm{C}$ as a general measure of the carbon chemistry of the deep Southern Ocean and more specifically as a measure of deep ocean circulation and ventilation [Charles and Fairbanks, 1992; Ninnemann and Charles, 2002]. With the uncertainty of the $\Delta$ age of gas-ice in mind, the main glacial-interglacial shifts in atmospheric carbon dioxide [Fischer et al., 1999] were essentially synchronous with changes in benthic foraminiferal $\delta^{13} \mathrm{C}$. This synchroneity characterized not only the penultimate deglaciation (Figure 9), but also other terminations as well (Figure 11). During the late interglacial stages (e.g., Stage 5e/d transition), atmospheric carbon dioxide remained high while other variables, including benthic foraminiferal $\delta^{13} \mathrm{C}$, shifted toward glacial conditions. Therefore not all variability is in common between the deep ocean record and the atmospheric $\mathrm{CO}_{2}$ record. However, we find no evidence for significant phase offsets between the switch to interglacial conditions in the carbon chemistry of the deep Southern Ocean and $\mathrm{CO}_{2}$ increases throughout length of the ice core. Thus the results of our correlation between planktonic foraminiferal $\delta^{18} \mathrm{O}$ and $\delta \mathrm{D}$ of ice necessarily imply a strong temporal connection between atmospheric $\mathrm{CO}_{2}$ variability and the physical and chem- 

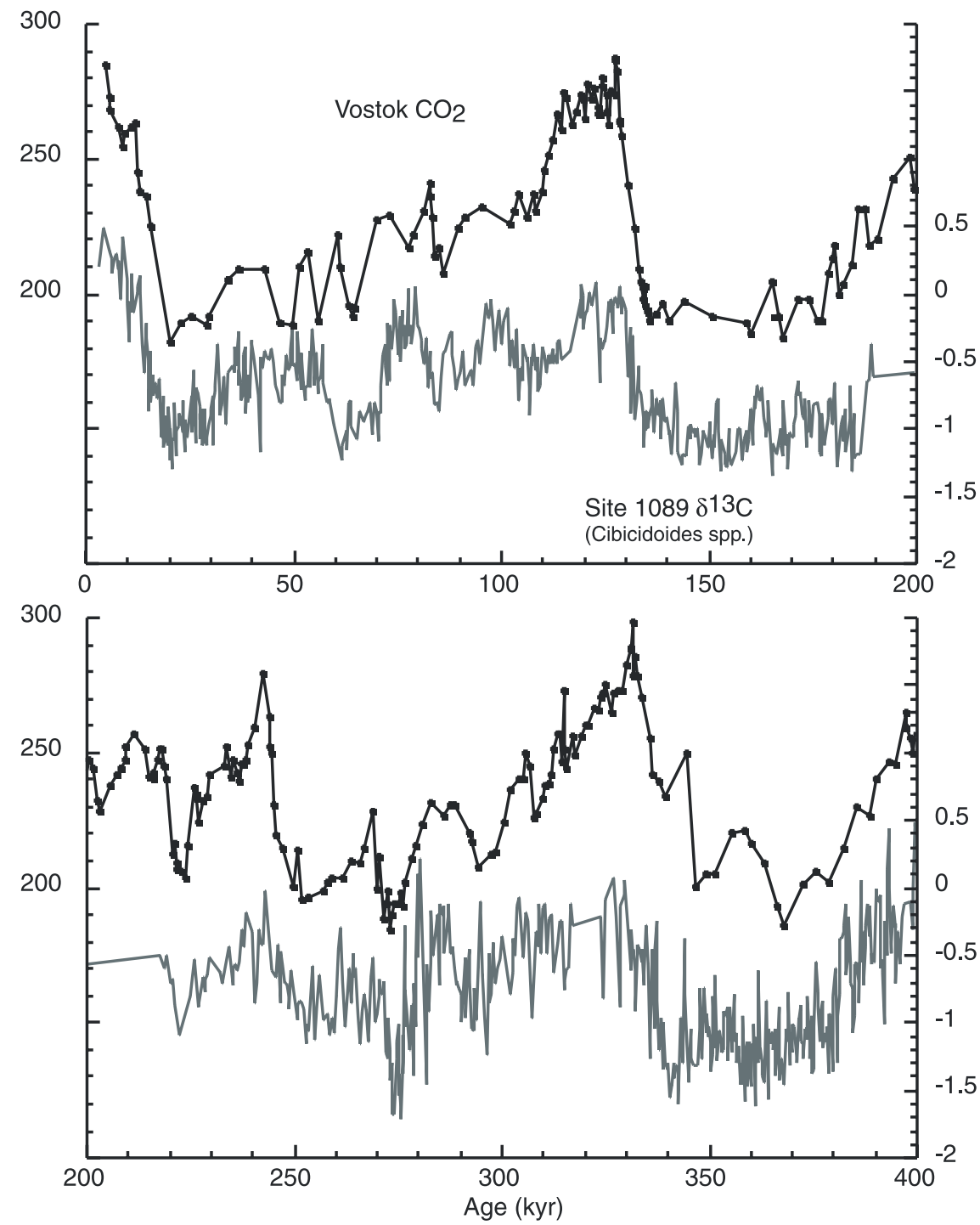

Figure 11. Relationship between the Site 1089 benthic foraminiferal $\delta^{13} \mathrm{C}$ record (lower curve, in \%o units) and the Vostok atmospheric $\mathrm{CO}_{2}$ record (upper curve, in ppmv). The ice core $\mathrm{CO}_{2}$ data and the gas age- ice age differences are from Petit et al. [1999], while the timescale is that developed here.

ical state of both the deep and surface Southern Ocean.

\section{Discussion}

[30] There have been a variety of previous efforts to link microfossil-based marine SST proxies to the record from Vostok [Pichon et al., 1992; Sowers et al., 1993; Waelbroeck et al., 1995], but we believe that the planktonic foraminiferal $\delta^{18} \mathrm{O}$ records from the northern subantarctic deep sea sediment drift deposit sites offer an especially appropriate marine target for comparison-if for no other reason than the resolution is broadly similar to that described by Petit et al. [1999] for the Vostok $\delta \mathrm{D}$ data. Our approach for comparison depends on the assumption that abrupt fluctuations in the subantarctic zone are recorded synchronously over central Antarctica. There is often a general (and perhaps legitimate) suspicion of any stratigraphic result that derives from such "wiggle matching" approaches [e.g., Crowley, 1999]. However, in this case, there is a strong and simple physical basis for the assumption: the subantarctic provides a dominant source of moisture to the interior of the Antarctic continent [Delaygue et 
al., 2000], and, on first principles, one would expect that abrupt events of any significance should be registered simultaneously in both archives. Furthermore, there is no a priori reason why the relative marine/atmospheric timing of abrupt events should evolve over ice age cycles, as it might for the lowerfrequency variations.

[31] Complications to this principle are conceivable of course, and other procedures for aligning the phase of marine and ice core signals are possible. However, the available independent chronological evidence from the last $60 \mathrm{ky}$ supports entirely the simplest assumption that the millennial scale features of marine and ice records are synchronous. For example, while we cannot rule out phase offsets of as much as several hundred years, proxies of magnetic field strength demonstrate that at least one of the stadial-interstadial events during MIS 3 shared a common timing between central Antarctica and the subantarctic South Atlantic. The same conclusion can be drawn from the "Antarctic Cold Reversal" at about $14 \mathrm{ka}$ that appears in Southern Ocean sediment cores both to the south and to the north of the subantarctic zone-for this event, radiocarbon constraints are precise enough to make an explicit marine/ice core link. Thus the observations justify the attempt to correlate many of the abrupt events in the older sections of the ice and deep-sea sediment cores.

[32] One might ask whether spatial heterogeneity affects the conclusions drawn from our marine/ice core correlation. This is a difficult question to address quantitatively, because the sedimentary sequences described here are the first in the Southern Ocean to resolve millennial scale events continuously through several glacial cycles. We can say that our extended marine-ice core comparison yields a chronology for Vostok ice that is (for the interval of overlap, the last 200 kyr) generally similar to one derived from direct orbital tuning [Waelbroeck et al., 1995]. Our results converge even more closely on the implications from Shackleton [2000], who used an independent strategy to tune the Vostok gas age chronology. Thus our synchronization produces results that do not conflict grossly with these previous attempts to tune the orbital scale variability in the ice core. The principal advantage of our correlation exercise is not that we derive a new absolute chronology of the ice core, but rather that the relative marine/ice chronology leads to the development of a detailed sequence of events in the Southern Ocean and polar atmosphere over ice age cycles, insight that cannot spring nearly as directly from other orbital tuning assumptions.

\subsection{Surface Climate Implications}

[33] A common response to surface temperature is the most plausible aspect of the climate system that would cause the apparent negative correlation between subantarctic foraminiferal $\delta^{18} \mathrm{O}$ and Vostok $\delta \mathrm{D}$ on millennial timescales. Foraminiferal $\delta^{18} \mathrm{O}$ certainly could be affected by changes in the regional hydrological cycle that alter the local seawater isotopic composition, but this explanation would imply positive correlation between marine and ice core isotopic records under most circumstances. A possible exception to this generalization could occur if the polar surface waters and atmosphere grew cold when the subantarctic waters freshened. However, the excursions in marine $\delta^{18} \mathrm{O}$ in cores south of the present polar front were apparently synchronous with their northern subantarctic counterparts, suggesting a common origin for the $\delta^{18} \mathrm{O}$ fluctuations throughout the high- latitude South Atlantic. Thus the millennial scale features in the $\delta^{18} \mathrm{O}$ profiles are, most likely, a product of SST excursions. It should be emphasized that this argument applies only to the millennial band, and we acknowledge that the processes occurring on the orbital timescale could be quite distinct from those operating on higher frequencies. One illustration of this difference is the fact that the millennial scale excursions in $\delta^{18} \mathrm{O}$ are resolved prominently in the South Atlantic, even though the glacial-interglacial amplitude of the foraminiferal $\delta^{18} \mathrm{O}$ in many cores does not exceed that expected through ice volume effects alone $(1 \%)$. The millennial scale isotopic variability in the northern subantarctic marine records bears the fingerprint of changes in water mass influence (subtropical versus polar) over the core sites [Ninnemann et al., 1999], and, therefore, we assume implicitly that the Vostok isotopic records must have been affected by a related set of processes. 
[34] Why then does the amplitude of foraminiferal $\delta^{18} \mathrm{O}$ diverge from Vostok $\delta \mathrm{D}$ on orbital timescales? One possible explanation involves seawater isotopic effects that are independent of temperature fluctuations. However, the problem with this explanation is that the divergence between the marine and ice core records does not follow the Northern Hemisphere glacial-interglacial cycle (cf Figure 7). Thus if the marine core-ice core isotopic difference resulted from continental ice volume effects, it would necessarily reflect the timing and localized influence of Antarctic ice melting. There are other possible biases in the marine record. For example, the sensitivity of $G$. bulloides $\delta^{18} \mathrm{O}$ to warm excursions might be damped above certain mean annual temperature levels in the subantarctic [Mortyn and Charles, 2003] because of species habitat. This possibility could be tested readily using different proxies for SST in the same sedimentary sequence. The limited number of direct comparisons that exist for the South Atlantic [e.g., Cortese and Abelmann, 2002; Rosenthal et al., manuscript in preparation, 2003] suggests that the structure of other SST proxies essentially follows that of planktonic foraminiferal $\delta^{18} \mathrm{O}$. Thus the lack of prominent ice core features such as deep glacial episodes (for example Stage 5d) cannot be strictly a product of foraminiferal habitat.

[35] Alternatively, the marine/ice core "residual" signal could be simply a measure of different sensitivity to orbital forcing between $40^{\circ} \mathrm{S}$ and $70^{\circ} \mathrm{S}$, brought about by, for example, sea ice variability. In principle, the combination of marine evidence and the ice core deuterium excess record might test such possibilities. The current explanation for changes in deuterium excess is that they result from changes in high- latitude moisture delivery to the Antarctic and changes in the temperature of the effective moisture source [Vimeux et al., 1999, 2001]. Our marine core/ice core synchronization implies that high deuterium excess corresponds closely with maximum $\delta^{18} \mathrm{O} / \delta \mathrm{D}$ difference and high values of subantarctic foraminiferal $\delta^{13} \mathrm{C}$. This coincidence of variables is difficult to explain if deuterium excess is taken as proxy for the temperature of a fixed subantarctic location (the co-occurrence of low $\delta^{18} \mathrm{O}$ anomalies with high $\delta^{13} \mathrm{C}$ anomalies is more characteristic of polar foraminiferal records). The sense of the $\delta^{13} \mathrm{C} / \mathrm{deu}-$ terium excess association is consistent with wind variability in the subantarctic zone: greater wind stress enhances the gas exchange effect on $\delta^{13} \mathrm{C}$ [Ninnemann and Charles, 1997], while decreasing the kinetic effect on evaporation of water isotopes that in part determines deuterium excess [Jouzel and Merlivat, 1984]. On the other hand, if the initial (evaporative) isotopic ratios are considered a minor influence on deuterium excess, then other meteorological phenomena must account for the marine/ice core correlations. The effect of sea ice on all these variables could be a possible area for further exploration -we speculate that sea ice might simultaneously influence the location of moisture sources, gas exchange rates and water mass mixing in the subantarctic.

\subsection{Atmosphere/Deep Ocean Links}

[36] Though there are a number of obvious pitfalls in assessing lead/lag relationships over abrupt events [see Alley et al., 2002], our results indicate that the main characteristics of the deep Southern Ocean and the polar atmosphere changed essentially simultaneously over the Terminations. The near synchroneity of the benthic foraminiferal isotopes and Vostok $\delta \mathrm{D}$ (the direct implication of our alignment of Vostok $\delta \mathrm{D}$ and planktonic foraminiferal $\delta^{18} \mathrm{O}$ ) carries several implications.

[37] For example, this synchroneity suggests that the same processes that warmed the Antarctic polar atmosphere also led to warming of the deep Southern Ocean, at least on 100,000-year timescales. Such tight physical coupling of the deep-ocean and polar atmosphere is often assumed to hold over glacial-interglacial cycles [e.g., Shackleton, 2000], but our records of the Terminations demonstrate the connections more explicitly. This correspondence also implies that we cannot use the Southern Ocean benthic foraminiferal $\delta^{18} \mathrm{O}$ record to deduce the precise timing of ice volume changes.

[38] However, because there are reasonable limits to deep-ocean cooling, we can establish reasonable 
maximum phase lags between Antarctic atmospheric temperature increase and initial ice sheet melting over the Terminations. We find that the first monotonic increases in polar temperatures preceded the onset of sea level rise by, at most, 2 kyr. Our comparisons further imply that the most direct proxy for ice volume in ice cores, $\delta^{18} \mathrm{O}$ atm, is itself lagged more significantly (3-4 ky) with respect to sea level than is commonly assumed. Thus it is also not appropriate to assume (as did Broecker and Henderson [1998] and Broecker [1998]) that changes in deep ocean circulation correspond with $\delta^{18} \mathrm{O}$ atm shifts as a general response to deglaciation. Our results make it clear that the conditions of the deep Southern Ocean (temperature, carbon chemistry) underwent substantial change well before any analogous decrease in $\delta^{18} \mathrm{O}$ atm.

[39] Instead, our atmosphere/deep ocean synchronization suggests that the processes controlling the main atmospheric $\mathrm{CO}_{2}$ shifts over ice age cycles were likely tied to Southern Ocean ventilation processes. Our observations are generally compatible with the mechanisms of $\mathrm{CO}_{2}$ variability outlined by Stephens and Keeling [2000] and Toggweiler [1999]. In these models, either sea ice meltback in the Antarctic (consistent with simultaneous warming in the deep and shallow Southern Ocean) or increased vertical mixing across the thermocline in the Antarctic (evidenced by carbon isotope excursions) allows the "venting" of $\mathrm{CO}_{2}$ from the deep Southern Ocean to the atmosphere. Furthermore, in these hypotheses, biological pump mechanisms for controlling $\mathrm{CO}_{2}$ variability play a secondary role to changes in the physical state of the surface Southern Ocean. Stephens and Keeling [2000] argue that the synchroneity between $\delta \mathrm{D}$ and $\mathrm{pCO}_{2}$ over Termination II in the Vostok ice core is perhaps the best available evidence supporting their proposal of strong surface ocean control of atmospheric $\mathrm{pCO}_{2}$. We can extend this line of reasoning directly by demonstrating that deep Southern Ocean properties changed simultaneously as well. Our results strongly suggest that shifts in deep ocean circulation (inferred from benthic foraminiferal $\delta^{13} \mathrm{C}$ ) are associated with major changes in atmospheric carbon dioxide. This observation does not rule out the possibility of changes in the biological pump, nor, for that matter, other influences on the $\mathrm{CO}_{2}$ budget of the atmosphere, such as the carbonate chemistry of the ocean. However, it does imply that physical mechanisms controlled the switch to higher $\mathrm{pCO}_{2}$ over deglaciations and, in the process, set the phase of the atmospheric $\mathrm{CO}_{2}$ response over the 100,000-year cycle.

\section{Acknowledgments}

[40] We thank Tom Guilderson for making the radiocarbon measurements, Jim Channell and Joe Stoner for making available their magnetic paleointensity data, Robbie Toggweiler and Ralph Keeling for discussion and collaboration, and Justin McCabe and Stephanie Mumma for technical assistance. A variety of anonymous reviewers helped improve earlier versions of the manuscript. This research was supported by NSF OCE9910416 (to CDC) and NSF 9907036 (to DAH).

\section{References}

Alley, R. B., E. J. Brook, and S. Anandakrishnan, A northern lead in the orbital band: North-south phasing of Ice-Age events, Quat. Sci. Rev., 21, 431-441, 2002.

Bard, E., Correction of accelerator mass spectrometry ${ }^{14} \mathrm{C}$ ages measured in planktonic foraminifera: Paleoceanographic implications, Paleoceanography, 3, 635-645, 1988.

Bard, E., B. Hamelin, R. G. Fairbanks, and A. Zindler, Calibration of the ${ }^{14} \mathrm{C}$ timescale over the past 30,000 years using mass spectrometric U-Th ages from Barbados corals, Nature, 345, 405-410, 1990.

Belkin, I. M., and A. L. Gordon, Southern Ocean fronts from the Greenwich meridian to Tasmania, J. Geophys. Res., 101, 3675-3696, 1996.

Bender, M., T. Sowers, M.-L. Dickson, J. Orchardo, P. Grootes, P. A. Mayewski, and D. A. Meese, Climate correlations between Greenland and Antarctica during the past 100,000 years, Nature, 372, 663-666, 1994.

Bender, M. L., B. Malaize, J. Orchardo, T. Sowers, and J. Jouzel, High precision correlations of Greenland and Antarctic ice core records over the last $100 \mathrm{kyr}$, in Mechanisms of Global Climate Change at Millennial Time Scales, Geophys. Monogr. Ser., vol. 112, edited by P. U. Clark, R. S. Webb, and L. D. Keigwin, pp. 149-164, AGU, Washington, D. C., 1999.

Blunier, T., and E. J. Brook, Timing of millennial-scale climate change in Antarctica and Greenland during the last glacial period, Science, 291, 109-112, 2001.

Blunier, T., et al., Asynchrony of Antarctic and Greenland climate change during the last glacial period, Nature, 394, 739-743, 1998.

Broekcer, W. S., The end of the present interglacial: How and when, Quat. Sci. Rev., 17, 689-694, 1998. 
Broecker, W. S., and G. M. Henderson, The sequence of events surrounding Termination II and their implications for the cause of glacial-interglacial $\mathrm{CO} 2$ changes, Paleoceanography, 13, 352-364, 1998.

Channell, J. E. T., J. S. Stoner, D. A. Hodell, and C. D. Charles, Geomagnetic paleointensity for the last $100 \mathrm{kyr}$ from the sub-antarctic South Atlantic: A tool for inter-hemispheric correlation, Earth Planet. Sci. Lett., 175, 145-160, 2000.

Charles, C. D., and R. G. Fairbanks, Evidence from Southern Ocean sediments for the effect of North Atlantic deep-water flux on climate, Nature, 355, 416-418, 1992.

Charles, C. D., J. Lynch-Stieglitz, U. S. Ninnemann, and R. G. Fairbanks, Climate connections between the hemisphere revealed by deep sea sediment core/ice core correlations, Earth Planet. Sci. Lett., 142, 19-27, 1996.

Cortese, G., and A. Abelmann, Radiolarian-based paleotemperatures during the last 160 kyrs at ODP Site 1089 (Southern Ocean, Atlantic Sector), Palaeogeogr. Palaeoclimatol. Palaeoecol., 182, 259-286, 2002.

Crowley, T. J., Correlating high-frequency climate variations, Paleoceanography, 14, 271-272, 1999.

Delaygue, G., V. Masson, J. Jouzel, R. D. Koster, and R. J. Healy, The origin of Antarctic precipitation: A modelling approach, Tellus Ser. B, 52, 19-36, 2000.

Fischer, H., M. Wahlen, J. Smith, D. Mastroianni, and B. Deck, Ice core records of atmospheric CO2 around the last three glacial terminations, Science, 283, 17121714, 1999.

Goldstein, S. J., D. W. Lea, S. Chakraborty, M. Kashgarian, and M. T. Murrell, Uranium-series and radiocarbon geochronology of deep-sea corals: Implications for Southern Ocean ventilation rates and the oceanic carbon cycle, Earth Planet. Sci. Lett., 193, 167-182, 2001.

Hays, J. D., J. Imbrie, and N. J. Shackleton, Variations in the Earth's orbit: Pacemakers of the ice ages, Science, 194, $1121-1132,1976$.

Hodell, D. A., C. D. Charles, and U. S. Ninnemann, Comparison of interglacial stages in the South Atlantic sector of the southern ocean for the past 450 kyrs: Implications for Marine Isotope Stage (MIS) 11, Global Planet. Change, 24, 7-26, 2000.

Hodell, D. A., C. D. Charles, and F. Sierro, Late Pleistocene evolution of the ocean's carbonate system, Earth Planet. Sci. Lett., 192, 109-124, 2001.

Hodell, D. A., C. D. Charles, J. H. Curtis, P. G. Mortyn, U. S. Ninnemann, and K. A. Venz, Data report: Oxygen isotope stratigraphy of ODP Leg 177 Sites 1088, 1089, 1090, 1093, and 1094, Proc. Ocean Drill. Program, Sci. Results, 177, 2003. (Available at http://www-odp.tamu.edu/publications/ 177_SR/).

Jouzel, J., and L. Merlivat, Deuterium and oxygen 18 in precipitation: Modeling of the isotopic effects during snow formation, J. Geophys. Res., 89, 11,749-11,757, 1984.

Jouzel, J., C. Lorius, J. R. Petit, C. Genthon, N. I. Barkoz, V. M. Kotyakov, and V. M. Petrov, Vostok ice core: A continuous isotope temperature record over the last climate cycle (160,000 years), Nature, 329, 403-408, 1987.
Kanfoush, S., D. A. Hodell, C. D. Charles, T. P. Guilderson, P. G. Mortyn, and U. S. Ninnemann, Millennial-scale instability of the Antarctic ice sheet during the last glaciation, Science, 288, 1815-1818, 2000.

Lorius, C., L. Merlivat, J. Jouzel, and M. Pourchet, A 30,000-yr isotope climatic record from Antarctic ice, Nature, 280, 644648, 1979.

Lorius, C., J. Jouzel, D. Raynaud, J. Hansen, and H. Le Treut, Greenhouse warming, climate sensitivity, and ice core data, Nature, 347, 139-145, 1990.

Martinson, D. G., N. G. Pisias, J. D. Hays, J. Imbrie, T. C. Moore Jr., and N. J. Shackleton, Age dating and the orbital theory of the ice ages: Development of a high-resolution 0 to 300,000-year chronostratigraphy, Quat. Res., 27, 1-29, 1987.

Mazaud, A., C. Laj, and M. Bender, A geomagnetic chronology for Antarctic ice accumulation, Geophys. Res. Lett., 21, 337-340, 1994.

Mortyn, P. G., Planktonic foraminifera and upper water column variability in the South Atlantic: A multiple species approach to the deep sea sedimentary record of climate change, Ph.D. Dissertation, Scripps. Inst. of Oceanogr., Univ. of Calif. San Diego, 2000.

Mortyn, P. G., and C. D. Charles, Planktonic foraminiferal depth habitat and $\delta^{18} \mathrm{O}$ calibrations: Plankton tow results from the Atlantic sector of the Southern Ocean, Paleoceanography, 18(2), 1037, doi:10.1029/2001PA000475, in press, 2003.

Ninnemann, U. S., and C. D. Charles, Regional differences in quaternary subantarctic nutrient cycling: Link to intermediate and deep water ventilation, Paleoceanography, 12, 560567, 1997.

Ninnemann, U. S., and C. D. Charles, Changes in the mode of Southern Ocean circulation over the last glacial cycle revealed by foraminiferal stable isotopic variability, Earth Planet. Sci. Lett., 201, 383-396, 2002.

Ninnemann, U. S., C. D. Charles, and D. A. Hodell, Origin of global millennial scale climate events: Constraints from the Southern Ocean deep sea sedimentary record, in Mechanisms of Global Climate Change at Millennial Time Scales, vol. 112, edited by P. U. Clark, R. S. Webb, and L. D. Keigwin, pp. 99-112, AGU, Washington, D. C., 1999.

Petit, J. R., et al., Climate and atmospheric history of the past 420,000 years from the Vostok ice core, Antarctica, Nature, 399, 429-436, 1999.

Pichon, J. J., L. D. Labeyrie, G. Bareille, M. Labracherie, J. Duprat, and J. Jouzel, Surface water temperature changes in the high latitudes of the southern hemisphere over the last glacial-interglacial cycle, Paleoceanography, 7, 289-318, 1992.

Shackleton, N., The 100,000-year ice-age cycle identified and found to lag temperature, carbon dioxide, and orbital eccentricity, Science, 289, 1897-1902, 2000.

Shackleton, N. J., A. Berger, and W. R. Peltier, An alternative astronomical calibration of the lower Pleistocene timescale based on ODP Site 677, Trans. R. Soc. Edinburgh Earth Sci., 81, 251-261, 1990. 
Sowers, T., M. Bender, L. Labeyrie, D. Martinson, J. Jouzel, D. Raynaud, J. J. Pichon, and Y. S. Korotkevich, A 13,5000year Vostok-SPECMAP common temporal framework, Paleoceanography, 8, 737-766, 1993.

Steig, E. J., E. J. Brook, J. W. C. White, C. M. Sucher, M. L. Bender, S. J. Lehman, D. L. Morse, E. D. Waddington, and G. D. Clow, Synchronous climate changes in Antarctica and the North Atlantic, Science, 282, 92-95, 1998.

Stevens, B. B., and R. F. Keeling, The influence of Antarctic sea ice on glacial-interglacial CO2 variations, Nature, 404, 171-174, 2000.

Stoner, J. S., J. E. T. Channell, D. A. Hodell, and C. D. Charles, A $\sim 580$ kyr paleomagnetic record from the subAntarctic South Atlantic (Ocean Drilling Program Site 1089), J. Geophys. Res., 108(B5), 2244, doi:10.1029/ 2001JB001390, 2003.
Toggweiler, J. R., Variation of atmospheric CO2 by ventilation of the ocean's deepest water, Paleoceanography, 14, 571588, 1999.

Vimeux, F., V. Masson, J. Jouzel, M. Stievenard, and J. R. Petit, Glacial-interglacial changes in ocean surface conditions in the Southern Hemisphere, Nature, 398, 410-413, 1999.

Vimeux, F., V. Masson, G. Delaygue, J. Jouzel, J. R. Petit, and M. Stievenard, A 420,000 year deuterium excess record from East Antarctica: Information on past changes in the origin of precipitation at Vostok, J. Geophys. Res., 106, 31,68331,873, 2001.

Waelbroeck, C., J. Jouzel, L. Labeyrie, C. Lorius, M. Labracherie, and N. I. Barkov, A comparison of the Vostok ice deuterium record and series from Southern Ocean core MD 88-770 over the last two glacial-interglacial cycles, Clim. Dyn., 12, 113-123, 1995. 